\title{
TECTA wt Allele
}

National Cancer Institute

\section{Source}

National Cancer Institute. TECTA wt Allele. NCI Thesaurus. Code C114417.

Human TECT A wild-type allele is located within 11q22-q24 and is approximately $90 \mathrm{~kb}$ in length. This allele, which encodes alpha-tectorin protein, is involved in the structure of the tectorial membrane. Mutation of the gene is associated with autosomal dominant deafness 8/12 and autosomal recessive deafness 21 . 